\title{
KETIDAKPASTIAN LINGKUNGAN ORGANISASI BERIMPLIKASI TERHADAP PEMILIHAN SISTEM PENGENDALIAN MANAJEMEN
}

\author{
Oleh: \\ Muhammad Nur El Farabi \\ Program Studi Informatika \\ Fakultas Teknik dan Ilmu Komputer \\ Universitas Indraprasta PGRI \\ Email: \\ pak.abi2305@gmail.com
}

\begin{abstract}
Management control systems in organizations are one of the important topics in management accounting. The selection of the right management control system is actually influenced by environmental uncertainty in the organization. It is necessary to review the literature regarding the implications of the uncertainty of the organization's environment on the selection of a management control system. This article is compiled based on the ideas supported by a literature review using content analysis. The content analysis stage starts from searching for relevant articles, selecting articles and collecting criteria for each article. The result is that the system changes that will be used are closely related to the organizational structure, objectives, and implementation of planning. This is because the control system itself actually means as a device of interconnected communication structures that facilitate information processing with the aim of helping management coordinate the parts that exist to achieve organizational goals on an ongoing basis. The uncertainty of the organization's environment clearly has on the selection of a management control system, so that with a rapidly changing environment the organization has implications for the need for more detailed information in order to maximize the function of the management control system.
\end{abstract}

Keywords: Organizational environmental uncertainty, literature study, management control systems 


\section{A. PENDAHULUAN}

Sistem pengendalian manajemen (SPM) pada organisasi merupakan salah satu sub topik penting dalam penelitian di bidang akuntansi manajemen (Speklé \& Widener, 2020). Sub topik ini banyak mendapat perhatian dari berbagai pihak diseluruh penjuru dunia. Terdapat beragam alasan mengapa SPM menjadi sangat penting bagi keberlangsungan suatu perusahaan. Pertama, SPM sangat penting dalam perumusan dan pengimplementasian strategi. SPM dikenal sebagai suatu sistem dan prosedur formal yang digunakan untuk menjaga informasi dari semua aktivitas perusahaan yang telah dirumuskan yang termasuk di dalamnya aktivitas perumusan dan pengimplementasian strategi.

Kedua, SPM sangat berperan utama untuk keunggulan bersaing organisasi dan keunggulan kinerja (Gerdin, 2020). SPM dengan sendirinya dijadikan sebagai alat untuk memudahkan perusahaan dalam menggunakan semua sumber daya baik yang bersifat terlihat maupun tidak terlihat untuk bersaing dengan kompetitornya. Oleh karena itu semua perusahaan berusaha agar orientasi perusahaan dan strategi bisnis dapat direfleksikan dalam SPM yang unggul dan kompeten. Refleksi akan terlihat baik jika organisasi memiliki mekanisme evaluasi yang tepat (Prasetyono, Kurniasari, \& Desnaranti, 2019).

Ketiga, SPM merupakan fungsi pengendali dalam organisasi (Groumpos, 2018). Hal ini berarti SPM memberikan makna bahwa kegagalan perusahaan adalah karena kegagalan dalam menjalankan SPM. Penggunaan SPM dalam perusahaan pada dasarnya berkaitan dengan tekanan yang bersifat positif maupun negatif. Hal ini berkaitan dengan dampak yang hasilkan oleh SPM bagi perusahaan. Oleh karena itu butuh suatu sistem pengukuran kinerja perusahaan yang sekaligus digunakan untuk perencanaan strategik (Sefudin, Prasetyono, \& Sasmoko, 2014). Hal ini mutlak diperlukan untuk memenangi persaingan pada era globalisasi.

Sejalan dengan semakin ketatnya persaingan saat ini, maka efisiensi kegiatan operasional organisasi merupakan salah satu strategi yang perlu dilakukan suatu organisasi. Untuk dapat menerapkan efisiensi tersebut diperlukan sistem pengendalian manajemen yang baik dimana hal tersebut tidak dapat terlepas dari tujuan dan planning yang ditentukan organisasi. Sistem kontrol itu sendiri sebenarnya adalah sebuah fungsi dari tujuan dan planning yang sering dipakai untuk mengukur pencapaian arah tujuan (Speklé \& Widener, 2020). Sedangkan fungsi planning adalah untuk memastikan kita berada di jalur yang benar untuk mencapai tujuan (Mahjoub, Atashsokhan, Khalilzadeh, Aghajanloo, \& Zohrehvandi, 2018). Oleh sebab itu sistem kontrol dan evaluasi yang baik dapat digunakan untuk kegiatan yang dapat meningkatkan produktivitas dan efisiensi organisasi (Prasetyono, 2016).

Meskipun sistem kontrol yang baik dapat meningkatkan produktivitas dan efisiensi organisasi, namun hal ini tetap dipengaruhi oleh lingkungan organisasi (Yustien, 2012). Lingkungan organisasi merupakan suatu tempat bagi organisasi beraktivitas dan memengaruhi efektivitas fungsi suatu organisasi (Spivack \& Woodside, 2019). Lingkungan organisasi ini dapat berubah dengan cepat sejalan dengan perubahan waktu, sedangkan perubahan kondisi lingkungan ada yang dapat dikendalikan atau karakteristik lingkungan mengalami kepastian tetapi ada kondisi 
lingkungan yang tidak dapat dikendalikan atau karakteristik lingkungan mengalami ketidakpastian (E. M. White, Aiken, Sloane, \& McHugh, 2020).

Kepastian maupun ketidakpastian lingkungan organisasi itu sangat berpengaruh atau berdampak pada fungsi-fungsi organisasi antara lain fungsi perencanaan, fungsi penentuan tujuan serta fungsi pengawasan (Chulvi, Agost, Felip, \& Gual, 2020). Ada dua ketidakpastian dalam lingkungan organisasi yaitu ketidakpastian yang sifatnya internal dan ketidakpastian yang sifatnya eksternal (Llorens, Navarro, Salas, Utzet, \& Moncada, 2019). Ketidakpastian tersebut sebenarnya akan menjadikan suatu cermin atau landasan di dalam pembuatan struktur organisasi yang lebih kompleks, sehingga akan tercipta sistem kontrol yang terperinci dan kompleks pula. Di dalam suatu kondisi ketidakpastian lingkungan organisasi maka aplikasi dari sebuah konsep pengawasan akan menjadi suatu persoalan. Suatu ketidakpastian lingkungan dapat mengakibatkan kesulitan di dalam menentukan suatu ukuran yang kuantitatif (Prasetyono \& Ramdayana, 2020).

Lingkungan yang tidak pasti akan banyak memengaruhi sistem kontrol yang digunakan karena dengan ketidakpastian tersebut informasi yang akan diperoleh organisasi akan beragam dan selalu berubah-ubah sehingga penetapan sistem yang akan digunakan juga akan lebih variatif (Martin, 2020). Hal ini merupakan suatu kebalikan dari lingkungan yang pasti. Pada suatu lingkungan organisasi yang stabil, unit-unit bisnis akan lebih sering mengadakan kontak dengan anggota organisasi sehingga pada kondisi ini tidak diperlukan suatu organisasi yang kompleks. Sementara pada suatu lingkungan yang tidak menentu secara tidak langsung akan memengaruhi pemilihan sistem pengendalian manajemen. Karena pada lingkungan yang demikian akan lebih mendorong orientasi organisasi untuk melihat masa depan yang tidak menentu dan mempertajam serta memperpendek periode informasi umpan balik (Crespo, Rodrigues, Samagaio, \& Silva, 2019).

Pada lingkungan yang tidak pasti terdapat ciri-ciri bahwa semua parameter tidak dapat direncanakan secara tepat dan semua parameter itu sangat memengaruhi efektivitas fungsi organisasi maka berdasarkan pemikiran tersebut serta melihat fakta-fakta yang ada saat ini, maka penulis membatasi uraian pada hal sebagai berikut: "ketidakpastian lingkungan organisasi berimplikasi terhadap pemilihan sistem pengendalian manajemen."

\section{B. KAJIAN PUSTAKA}

\section{Lingkungan Organisasi}

Setiap organisasi mempunyai lingkungan yang berbeda-beda. Lingkungan organisasi yaitu baik intern maupun ekstern sangat memengaruhi atau berdampak terhadap efektivitas maupun efisiensi dari operasional organisasi tersebut. Lingkungan organisasi ini dapat berubah dengan cepat sejalan dengan waktu yang berubah, dimana perubahan ini ada yang dapat dikendalikan dan ada yang tidak dapat dikendalikan.

Lingkungan organisasi adalah pola kondisi-kondisi atau faktor-faktor internal maupun eksternal yang memengaruhi atau menuntun ke arah kemampuan mengetahui kekuatan, kelemahan, kesempatan atau ancaman-ancaman pada kehidupan dan pengembangan organisasi, lingkungan secara relevan memengaruhi 
proses atau operasi keputusan strategi (Prasetyono, Ramdayana, \& Estiningsih, 2020). Organisasi ini dapat berubah dengan cepat sejalan dengan waktu yang berubah, dimana perubahan ini ada yang dapat dikendalikan dan ada yang tidak dapat dikendalikan. Elemen-elemen lingkungan organisasi yang berasal dari internal organisasi di antaranya adalah personel organisasi, fungsi organisasi, komponen unit staf dan komponen level organisasi. Sedangkan elemen-elemen lingkungan organisasi yang berasal dari eksternal organisasi di antaranya adalah konsumen, supplier, kompetitor, sospol dan perkembangan teknologi (Chulvi et al., 2020).

Pada dasarnya lingkungan organisasi dapat dibagi menjadi dua bagian, yaitu kepastian lingkungan organisasi dan ketidakpastian lingkungan organisasi (Wei, Sewell, Woody, \& Rose, 2018). Pada kepastian lingkungan organisasi, semua parameter dapat direncanakan dan dapat terukur atau diukur secara kuantitatif termasuk penentuan tujuan, planning dan controlling, sedangkan pada ketidakpastian lingkungan organisasi seluruh parameter berubah-ubah dengan sangat cepat, sehingga penentuan tujuan, planning dan kontrol dilakukan secara kualitatif. Terdapat dua jenis ketidakpastian lingkungan organisasi yaitu ketidakpastian yang sifatnya internal dan ketidakpastian yang sifatnya eksternal (Kim et al., 2020). Ketidakpastian yang berasal dari internal organisasi di antaranya adalah personel organisasi, fungsi organisasi, komponen unit staf dan komponen level organisasi. Ketidakpastian yang berasal dari eksternal organisasi di antaranya adalah konsumen, supplier, kompetitor, sospol dan teknologi.

Dari kedua jenis ketidakpastian lingkungan organisasi tersebut di atas akan banyak memengaruhi struktur organisasi yang akan digunakan, serta penetapan tujuan maupun perencanaannya juga akan berbeda, yang pada akhirnya rangkai tersebut akan banyak memengaruhi penetapan sistem kontrol manajemen yang akan digunakan (Crespo et al., 2019). Semakin banyak dan cepat informasi-informasi ketidakpastian lingkungan tersebut diperoleh organisasi, semakin cepat pula pengambilan keputusan maupun perubahan sistem kontrol manajemen yang akan digunakan (Groumpos, 2018). Seorang pemimpin perusahaan harus dapat mengatasi hal tersebut dengan menggunakan pendekatan kepemimpinan yang sesuai demi meredam ketidakpastian lingkungan yang terjadi (Prasetyono et al., 2020).

Dalam ketidakpastian lingkungan organisasi, maka setiap organisasi akan berusaha semaksimal mungkin mengantisipasinya di dalam menerapkan strategi atau menjalankan fungsi-fungsi manajemen (Lancaster, 2005). Sehubungan dengan hal tersebut di dalam menjalankan fungsi-fungsi manajemen seperti penetapan tujuan, perencanaan, serta pengawasan maka manajemen setiap organisasi harus melihat variabel-variabel lingkungannya. Secara umum manajemen setiap organisasi akan terlebih dahulu melihat faktor-faktor apa yang akan menjadi kekuatan, kelemahan, peluang serta ancaman dari organisasi tersebut (Huffmire \& Holmes, 2006).

Tujuan organisasi dapat diartikan sebagai suatu pernyataan kuantitatif dari beberapa imajinasi tentang suatu keadaan yang secara sadar ingin dicapai pada masa yang akan datang dengan tujuan untuk menetapkan standar yang harus dipenuhi sebagai tolak ukur keberhasilan suatu misi (Robert Kreitner, 2009). 
Tujuan dalam suatu organisasi dapat dibedakan menjadi dua (Daft, 2008), yaitu: Official tujuan yang berarti menyatakan suatu tujuan umum memberikan gambaran suatu sistem nilai organisasi, sehingga official tujuan bersifat abstrak, vaque, tidak spesifik dan sulit diukur. Official tujuan juga merupakan legitimasi dari eksistensi perusahaan; Operative tujuan yang berarti menggambarkan aktivitas operasional yang sesungguhnya diminati/diinginkan, sehingga rencana perusahaan dan pengawasan dapat diperoleh. Operative tujuan mempunyai tiga fungsi, yaitu sebagai direction (arahan), sebagai pedoman pembuatan keputusan criteria performance dan meminimalkan ketidakpastian. Operative tujuan lebih konkrit dan spesifik dan dapat diukur.

Penyusunan tujuan dalam organisasi perlu memperhatikan elemen-elemen tertentu, yaitu: 1) Sesuai, yang berarti tujuan harus mempunyai sumbangan yang berarti untuk menggerakkan organisasi dalam arah yang benar untuk mencapai misinya; 2) Layak, yang berarti tujuan adalah sesuatu yang benar-benar dapat dicapai oleh organisasi dengan sumber daya yang tersedia; 3 ) Lentur, yang berarti tujuan harus dimungkinkan untuk dimodifikasi dimasa akan datang jika keadaan mendesak karena adanya perubahan lingkungan yang mendadak; 4) Memotivasi, yang berarti tujuan yang baik adalah yang dapat memotivasi anggota organisasi untuk mencapainya, sehingga tujuan tidak harus terlalu mudah ataupun terlalu sulit dan menyebabkan hal tersebut di luar jangkauan organisasi; 5) Dapat dimengerti, yang berarti bahasa yang digunakan untuk menyatakan tujuan haruslah mudah dipahami sehingga pihak-pihak yang terkait dalam pencapaiannya tidak mengalami kebingungan; 6) Terkait, yang berarti tujuan haruslah konsisten dan mendukung misi organisasi. Pencapaian tujuan diharapkan mencerminkan pencapaian misi organisasi; 7) Dapat diukur, yang berarti tujuan harus jelas dan terukur, misalnya dengan metode kuantitatif.

Penetapan tujuan merupakan hasil persepsi terhadap lingkungan, sehingga ada kaitannya antara ketidakpastian lingkungan dan persepsi terhadap ketidakpastian lingkungan (Robbins \& Coulter, 2012). Jika persepsinya akurat maka dapat disusun tujuan dan strateginya. Bila kemudian terjadi perubahan pada karakteristik lingkungan, maka organisasi perlu melakukan perubahan pada tujuannya. Selama masa perubahan tujuan, tujuan yang baru ditambahkan pada tujuan yang lama dan seterusnya, sampai akhirnya tujuan yang baru menjadi pengganti tujuan yang lama. Perubahan tujuan yang terjadi pada situasi ketidakpastian akan menyebabkan pihak manajemen di dalam membuat perencanaan dan di dalam menjalankan fungsi pengawasan harus lebih fleksibel dibanding dengan dalam kondisi lingkungan yang pasti. Sehingga dengan dimungkinkannya perubahan tujuan, maka akan berpengaruh pada perencanaan dan pengawasan, sehingga organisasi tersebut seharusnya lebih fleksibel dalam perencanaan, harus beradaptasi dengan lingkungannya, harus lebih banyak belajar dari keadaan yang sedang terjadi, dan harus dapat memberikan respon terhadap lingkungan yang memengaruhinya (Gibson, Ivancevich, James H. Donnelly, \& Konopaske, 2012). 


\section{Perencanaan Organisasi}

Di dalam menentukan perencanaan organisasi, setiap organisasi harus mempertimbangkan setiap aspek lingkungan organisasi sebab seperti yang telah diketahui lingkungan organisasi ini mempunyai peran yang penting. Dalam lingkungan yang tidak pasti, menurut Kulkalis dalam White (2004) perencanaan didefinisikan sebagai "Collectively the conceptual empirical work to date leads one to conclude that the impact of firm and environmental characteristics on strategic planning processes is still not clearly understood." Sedangkan pada lingkungan yang pasti, menurut Steiner dalam Alkhafaji (2013) maka perencanaan didefinisikan sebagai “... a process that begins with objectives; defines strategies, policies, and detailed plans to achieve them; which establishes an organisation to implement decisions; and includes a review of performance and feedback to introduce a new planning cycle."

Penyusunan perencanaan dalam organisasi melibatkan elemen-elemen yang perlu diperhatikan dapat dibagi menjadi empat dimensi: 1) Movement adalah tingkat perubahan elemen lingkungan internal dan atau eksternal yang sering dinyatakan sebagai tetap atau statis dan dinamis. Menurut pendapat Burns \& Stalker dalam White (2004) bahwa dimensi-dimensi lingkungan organisasi yang digunakan adalah tetap dan dinamis, dan mengacu pada tingkatan perubahan di dalam lingkungan termasuk elemen eksternal, seperti: customers, competitors, suppliers, regulatory groups, serta elemen internal seperti perubahan teknologi; 2) Content adalah faktor-faktor kegiatan elemen lingkungan intern dan atau ekstern yang harus dipertimbangkan di dalam pembuatan keputusan. Dimensi ini sering disebut sebagai homogeneity dan heterogeneity; 3) Time Frame of Feedback Information. Dimensi ini berhubungan dengan jangka waktu yang dipergunakan untuk merespon stimulus (panjang/pendeknya waktu yang dibutuhkan untuk proses umpan balik informasi) tingkat perubahan unsur-unsur lingkungan internal (dalam organisasi) dan lingkungan eksternal (luar organisasi) yang biasanya digambarkan sebagai sesuatu yang stabil atau dinamis; 4) Predictability merupakan kemampuan untuk membuat prediksi keadaan atau konsekuensi masa yang akan datang, sehingga tindakan yang diperlukan dapat diambil segera.

Ketidakpastian lingkungan tentunya akan berdampak dalam membuat suatu perencanaan organisasi. Manajemen setiap organisasi akan terlebih dahulu melihat faktor-faktor apa yang menjadi kekuatan, kelemahan, peluang, serta ancaman dari organisasi tersebut. Oleh sebab itu manajemen setiap organisasi di dalam membuat perencanaannya harus lebih fleksibel dibanding dengan dalam kondisi lingkungan yang pasti, sehingga diperlukan berbagai alternatif untuk mengantisipasi keadaan dimasa yang akan datang yang kadangkala tidak dapat diprediksi. Perencanaan organisasi yang bersifat fleksibel, maka fungsi kontrol pun harus dapat mengikuti perubahan perencanaan tersebut. Karena ketidakpastian lingkungan perencanaan organisasi harus lebih fleksibel, hal ini akan memengaruhi sistem pengawasan yang akan digunakan karena ketidakpastian tersebut informasi yang akan diperoleh organisasi akan beragam dan selalu berubah-ubah sehingga sistem pengawasan yang digunakanpun akan bervariatif. 


\section{Sistem Pengendalian Manajemen}

Management Control System (CS) sering dipakai untuk mengukur dan mengikuti arah tujuan yang akan dicapai, sedangkan fungsi planning untuk memastikan kita berada di jalur yang benar untuk mencapai tujuan tersebut. Manajemen CS merupakan sistem pengawasan manajemen yang memiliki kegiatan perencanaan dan pengendalian kegiatan yang terjadi pada suatu organisasi yang merupakan proses untuk mengarahkan organisasi mencapai tujuan yang telah ditetapkan (Gerdin, 2020). Elemen dari CS terdiri atas desired ends, actors, control tools, dan control type (Martin, 2020).

Desired ends merupakan tujuan akhir organisasi, memiliki dua elemen terdiri atas: 1) Yardstics (alat pengukur), yaitu alat untuk mengukur progres dari suatu kegiatan atau hasil suatu kegiatan; 2) Direction (arah kegiatan), yaitu arah kegiatan yang menjelaskan mengenai arah dan pencapaian tujuan yang ditentukan. Actors merupakan seseorang yang terlibat dalam management control system yang relevan dalam membuat keputusan. Dalam hal ini terdiri dari behavioural, motivational, domination, power, dan decision space. Control Tools merupakan alat bantu untuk menjanlankan fungsi kontrol yang terdiri atas value of representation, yaitu dengan mempertimbangkan kondisi internal, eksternal dan sosial; dan dimensions (batasanbatasan), yaitu dengan mempertimbangkan directional, bureaucratic, scientific dan financial. Control Type terdiri atas formal, yaitu type fungsi kontrol yang memiliki aturan pengontrolannya dan informal, seperti dengan cara survallence yaitu mengontrol tanpa sepengetahuan orang yang dikontrol atau dengan cara cultural yaitu mengontrol sesuai dengan culture dalam unit-unit organisasi (Speklé \& Widener, 2020).

Saat penerapan fungsi kontrol terdiri dari tiga tahap, yaitu input control, behaviour control dan output control. Input control merupakan tahap pertama yang meliputi pemilihan dan penetapan input yang digunakan untuk suatu kegiatan yang dilakukan. Behaviour control merupakan tahap kedua yang meliputi penilaian proses operasi untuk menilai bagaimana pekerjaan-pekerjaan tersebut dijalankan. Output control merupakan tahap ketiga setelah operasi tersebut dijalankan untuk menilai bagaimana output yang telah dicapai (Liew, 2019).

Ketidakpastian lingkungan akan berpengaruh terhadap pemilihan management control system. Pada suatu tingkat ketidakpastian yang tinggi akan mendorong organisasi menjadi lebih berorientasi ke masa depan dan memperpendek periode informasi umpan balik. Di samping itu, peningkatan ketidakpastian akan menyebabkan control tools yang ada menjadi kurang efektif dan sebaiknya diganti dengan kombinasi control tools lainnya (Accorsi et al., 2019).

\section{METODE PENELITIAN}

Artikel ini disusun berdasarkan hasil pemikiran yang didukung oleh tinjauan pustaka menggunakan analisis isi (Lafuente-Ruiz-de-Sabando, Zorrilla, \& Forcada, 2018). Sebuah tinjauan pustaka telah diadopsi sebagai metodologi penelitian (Damiani, Demartini, Guizzi, Revetria, \& Tonelli, 2018). Sebuah tinjauan pustaka tentang topik tertentu bermanfaat jika ada minat dan akumulasi penelitian tentang 
topik itu (Twizeyimana \& Andersson, 2019), Tinjauan pustaka terstruktur didefinisikan sebagai tinjauan yang lebih naratif karena pendekatan metodisnya, yang menyiratkan penjelasan rinci tentang langkah-langkah yang diambil untuk memilih, memindai dan menganalisis literatur, yang bertujuan untuk mengurangi bias dan meningkatkan transparansi (Dixit, Mandal, Thanikal, \& Saurabh, 2019).

Pertama-tama, penulis mengumpulkan makalah melalui pencarian database elektronik berikut: google cendikia, EBSCO Host, ProQuest, dan Science Direct. Pencarian dilakukan dengan menggabungkan empat kata kunci pertama dengan enam kata kunci terakhir (Jamshidi, Jamshidi, Ait-kadi, \& Ramudhin, 2019). Kata kunci yang digunakan dalam penelusuran literatur adalah ketidakpastian lingkungan organisasi dan pemilihan sistem pengendalian manajemen. Berdasarkan hasil pencarian, diperoleh 21 artikel yang diterbitkan antara tahun 1999 hingga 2020. Tahap kedua, seleksi makalah, penulis meneliti abstrak dari masing-masing makalah dan menemukan 14 artikel yang memenuhi kriteria (Copaci \& Rusu, 2015). Kriteria yang digunakan untuk makalah yang membahas ketidakpastian lingkungan organisasi dan pemilihan sistem pengendalian manajemen. Hasil data dari studi pustaka dikelompokkan dan diurutkan sesuai dengan penelitian. Selanjutnya, hasil pengelompokan teori dan kajian empiris dari jurnal-jurnal tersebut digeneralisasi oleh penulis untuk menjawab rumusan masalah yang sesuai dengan ketidakpastian lingkungan organisasi sehingga berimplikasi pada pemilihan sistem pengendalian manajemen.

\section{HASIL DAN PEMBAHASAN}

Di dalam membuat perencanaan organisasi pada lingkungan yang tidak pasti menghendaki setiap organisasi untuk menggunakan perencanaan yang fleksibel dan dinamis dibandingkan dengan keadaan yang pasti. Masalah ketidakpastian lingkungan biasanya tidak dapat dipecahkan dengan mengurangi sumber-sumber ketidakpastian, karena sumber ketidakpastian bisa diakibatkan oleh kombinasi faktor-faktor lingkungan. Pada dasarnya organisasi tidak dapat mengubah lingkungan, karena organisasi itu dihasilkan oleh faktor-faktor lingkungan intern dan ekstern dan organisasi tidak memiliki kemampuan untuk mengubahnya. Sebagai contoh adalah adanya krisis moneter yang berkepanjangan yang terjadi sejak pertengahan tahun 1998 telah menyebabkan kontraksi pertumbuhan ekonomi dan turunnya prospek sebagian besar usaha di Indonesia sebagai akibat tingginya suku bunga bank, meningkatnya harga barang, berfluktuasi nilai valuta asing serta turunya daya beli masyarakat.

Sebagaimana perencanaan organisasi, penentuan tujuan juga sangat berkaitan dengan karakteristik lingkungan organisasi, dalam hal ini bahwa semakin tinggi kesesuaian antara persepsi terhadap ketidakpastian lingkungan dengan ketidakpastian struktural maka akan diperoleh kinerja ekonomi yang lebih baik. Selain daripada itu, persepsi terhadap ketidakpastian lingkungan dengan keanekaragaman tujuan adalah meningkat dan menurun secara bersama-sama. Keduanya akan bergerak secara berlawanan arah terhadap hal yang terjadi antara persepsi terhadap ketidakpastian lingkungan dengan ketidakpastian struktural.

Pengaruh karakteristik ketidakpastian lingkungan atas pemilihan control system ditunjukkan oleh hubungan antara control system dengan elemen organisasi 
lainnya seperti struktur organisasi, interdependensi antar departemen, dan management style. Walaupun studi ini tidak mencakup tujuan organisasi dan sistem perencanaan di dalam pengujiannya, tetapi mereka melengkapi dengan bukti empiris bahwa ketidakpastian lingkungan memengaruhi pemilihan control system.

Gordon \& Narayanan dalam Huffmire \& Holmes (2006) menguji hubungan antara Sistem Akuntansi Manajemen, Ketidakpastian lingkungan yang dirasakan dan struktur organisasi pada tiga orang manajer senior dari 40 perusahaan di Amerika Serikat. Mereka menemukan bahwa tingkat dari perceived environmental uncertainty mempunyai hubungan yang positif dengan pemilihan struktur organisasi. Perceived environmental uncertainty akan memengaruhi anggotaanggota organisasi untuk bergerak menuju suatu bentuk struktur yang organik yang dicirikan oleh kemampuan memproses informasi yang lebih tinggi Gordon \& Narayanan dalam Groumpos (2018). Lebih dari itu sebagai pengambil keputusan dalam ketidakpastian lingkungan yang lebih besar diperlukan informasi tambahan berbentuk informasi eksternal, non keuangan. Studi ini mengindikasikan beberapa temuan. Di dalam pooled interdependency, SOP merupakan control system yang lebih penting daripada anggaran dan laporan statistik. Anggaran dan laporan statistik menjadi sangat berkaitan dengan sequential interdependency, dimana SOP lebih sedikit digunakan di dalam lingkungan tersebut.

Studi empiris menunjukkan bahwa karakteristik lingkungan bisa memengaruhi pemilihan control system. Studi oleh Govindarajan \& Narayanan dalam Samagaio, Crespo, \& Rodrigues (2018) menunjukkan bahwa ketidakpastian lingkungan mendorong anggota-anggota suatu organisasi merespon lebih cepat dan karena itu akan meningkatkan tingkat kecepatan control tools. Untuk merespon lebih cepat, organisasi mungkin memerlukan suatu bentuk struktur yang organic yang akan mempunyai kemampuan informasi yang lebih banyak.

Dalam ketidakpastian, pembuat keputusan akan memerlukan lebih banyak informasi yang diorientasikan ke masa depan dan ini didukung oleh Gordon \& Narayan dalam Groumpos (2018) yang menemukan bahwa organisasi memerlukan informasi eksternal dan non keuangan untuk memperbaiki kemampuannya dalam membuat suatu prediksi. Di dalam hal interdependency, Macintosh \& Daft dalam Gurd \& Helliar (2017) melakukan suatu studi yang meneliti hubungan antara ketergantungan antar departemen dengan management control system pada 25 organisasi. Ketergantungan tersebut diukur dengan aliran-aliran kerja antara unit yang diuji dengan unit-unit lainnya. Studi ini menunjukkan bahwa interdependensi yang lebih tinggi makin sedikit menggunakan SOP dan anggaran operasional dan lebih banyak menggunakan laporan statistik. Penemuan ini bisa diinterpretasikan sebagai dukungan atas pernyataan bahwa struktur organisasi sebaga suatu faktor penentu dari ketergantungan dapat menjadi sumber ketidakpastian. Di dalam ketidakpastian, organisasi perlu informasi lebih rinci, suatu jangka waktu yang pendek dan data non-keuangan seperti ditunjukkan oleh laporan statistik.

SOP yang menyediakan informasi bulanan tentang kemajuan menuju target anggaran dan anggaran operasional yang terdiri dari ketentuan untuk menangani operasi yang menggambarkan suatu ciri control system yang kaku. Perubahan SOP dan anggaran operasional ke laporan statistik dimana ketidakpastian meningkat bisa diinterpretasikan sebagai suatu perubahan dari tipe kontrol yang kaku dan ketat ke 
ciri control system yang subjektif atau kurang ketat, dan kurang menekankan pada data keuangan. Sementara itu, dapat disimpulkan bahwa, bila lingkungan menjadi lebih tidak pasti, beberapa ciri control system akan berubah (Dewantoro, 2011). Di dalam ketidakpastian, organisasi perlu informasi lebih, dan tidak semata-mata mengandalkan pada data keuangan, oleh karena itu perlu informasi lain untuk menggambarkan situasi yang ada (Accorsi et al., 2019). Untuk melakukan reaksi yang segera terhadap perubahan di dalam lingkungan, organisasi perlu informasi lebih rinci dan suatu peningkatan di dalam frekuensi system monitoring. Selain itu, peningkatan ketidakpastian lingkungan yang disebabkan oleh ketidakpastian yang menyarankan pengukuran performansi akan terjadi perubahan sistem evaluasi yang didasarkan atas formula menjadi sistem evaluasi yang berdasarkan non-formula.

Ketidakpastian lingkungan dapat berimplikasi pada pemilihan pengendalian sistem manajemen yang sesuai. Pemilihan tersebut dalam bentuk operasionalnya dapat menggunakan SOP yang lebih rijit agar dapat meminimalisir dampak dari lingkungan yang selalu berubah.

\section{E. SIMPULAN}

Berdasarkan seluruh pembahasan tersebut maka dapat disimpulkan bahwa untuk membuat perencanaan di dalam lingkungan yang tidak pasti setiap organisasi hendaknya menggunakan perencanaan yang fleksibel dan dinamis dibandingkan dengan keadaan yang pasti dengan keterbatasan dalam menentukan antisipasi krisis dimasa yang akan datang. Setiap manajemen organisasi harus selalu me-review perencanaannya serta harus beradaptasi dan selalu merespon keadaan lingkungan yang memengaruhinya. Penentuan tujuan merupakan hasil persepsi terhadap lingkungan, sehingga ada kaitannya antara ketidakpastian struktur lingkungan dan persepsi terhadap ketidakpastian lingkungan. Perubahan sistem yang akan digunakan sangat terkait dengan struktur organisasi, tujuan, dan pelaksanaan perencanaan. Hal ini disebabkan karena sistem pengendalian itu sendiri yang sebenarnya bermakna sebagai perangkat struktur komunikasi yang saling berhubungan yang memudahkan pemrosesan informasi dengan maksud membantu manajemen mengkoordinasikan bagian-bagian yang ada untuk mencapai tujuantujuan organisasi secara terus-menerus. Ketidakpastian lingkungan organisasi jelas memiliki pada pemilihan sistem pengendalian manajemen, sehingga dengan adanya suatu perubahan lingkungan secara cepat organisasi berimplikasi pada kebutuhan informasi yang lebih terperinci untuk dapat memaksimalkan fungsi sistem pengendalian manajemen. 


\section{DAFTAR PUSTAKA}

Accorsi, R., Gallo, A., Tufano, A., Bortolini, M., Penazzi, S., \& Manzini, R. (2019). A tailored maintenance management system to kontrol spare parts life cycle. Procedia Manufacturing, 38(2019), 92-99. https://doi.org/10.1016/j.promfg.2020.01.013

Alkhafaji, A. F. (2013). Strategic management: formulation, implementation, and kontrol in a dynamic environment. New York: The Haworth Press, Inc.

Chulvi, V., Agost, M. J., Felip, F., \& Gual, J. (2020). Natural elements in the designer's work environment influence the creativity of their results. Journal of Building Engineering, 28(October 2019), 101033. https://doi.org/10.1016/j.jobe.2019.101033

Copaci, I. A., \& Rusu, A. S. (2015). A Profile Outline of Higher Education ETutoring Programs for the Digital-Native Student - Literature Review. Procedia - Social and Behavioral Sciences, 209(July), 145-153. https://doi.org/10.1016/j.sbspro.2015.11.270

Crespo, N. F., Rodrigues, R., Samagaio, A., \& Silva, G. M. (2019). The adoption of management control systems by start-ups: Internal factors and context as determinants. Journal of Business Research, 101(June), 875-884. https://doi.org/10.1016/j.jbusres.2018.11.020

Daft, R. L. (2008). Management (Eighth). Mason: Thomson South-Western.

Damiani, L., Demartini, M., Guizzi, G., Revetria, R., \& Tonelli, F. (2018). Augmented and Virtual Reality Applications in Industrial Systems: A Qualitative Review Towards the Industry 4.0 Era. IFAC-PapersOnLine, 51(11), 624-630. https://doi.org/10.1016/j.ifacol.2018.08.388

Dewantoro, D. (2011). Pengaruh Kekuatan Keluarga Terhadap Kinerja Melalui Sistem Pengendalian Manajemen Pada Perusahaan Keluarga Di Surabaya. Majalah Ekonomi Universitas Airlangga, 21(3), 294-310.

Dixit, S., Mandal, S. N., Thanikal, J. V., \& Saurabh, K. (2019). Evolution of studies in construction productivity: A systematic literature review (2006-2017). Ain Shams Engineering Journal, (xxx). https://doi.org/10.1016/j.asej.2018.10.010

Gerdin, J. (2020). Management kontrol as a system: Integrating and extending theorizing on MC complementarity and institutional logics. Management Accounting Research, (October 2018), 100716. https://doi.org/10.1016/j.mar.2020.100716

Gibson, J. L., Ivancevich, J. M., James H. Donnelly, J., \& Konopaske, R. (2012). Organizations Behavior, Structure, Processes.

Groumpos, P. P. (2018). Advanced automation control systems (AACS) for Energy and Comfort Management in a Building Environment. IFAC-PapersOnLine, 51(30), 34-38. https://doi.org/10.1016/j.ifacol.2018.11.241 
Gurd, B., \& Helliar, C. (2017). Looking for leaders: 'Balancing' innovation, risk and management control systems. British Accounting Review, 49(1), 91-102. https://doi.org/10.1016/j.bar.2016.10.008

Huffmire, D. W., \& Holmes, J. D. (2006). Handbook of Effective Management: How to Manage or Supervise Strategically. London: Praeger.

Jamshidi, A., Jamshidi, F., Ait-kadi, D., \& Ramudhin, A. (2019). Applied Risk Analysis Approaches for Maintenance of Offshore Wind Turbines; Applied Applied Risk Maintenance Offshore Wind Wind Turbines; Turbines; A Literature Applied Maintenance Offshore Applied Risk Maintenance Offshore. IFAC PapersOnLine, 52(13), 1075-1078. https://doi.org/10.1016/j.ifacol.2019.11.338

Kim, L. Y., Rose, D. E., Ganz, D. A., Giannitrapani, K. F., Yano, E. M., Rubenstein, L. V., \& Stockdale, S. E. (2020). Elements of the healthy work environment associated with lower primary care nurse burnout. Nursing Outlook, 68(1), 14-25. https://doi.org/10.1016/j.outlook.2019.06.018

Lafuente-Ruiz-de-Sabando, A., Zorrilla, P., \& Forcada, J. (2018). A Review of Higher Education Image and Reputation Literature: Knowledge Gaps and A Research Agenda. European Research on Management and Business Economics, 24(1), 8-16. https://doi.org/10.1016/j.iedeen.2017.06.005

Lancaster, G. (2005). Research Methods in Management. Amsterdam: Elsivier.

Liew, A. (2019). Enhancing and enabling management control systems through information technology: The essential roles of internal transparency and global transparency. International Journal of Accounting Information Systems, 33, 16-31. https://doi.org/10.1016/j.accinf.2019.03.001

Llorens, C., Navarro, A., Salas, S., Utzet, M., \& Moncada, S. (2019). For better or for worse? Psychosocial work environment and direct participation practices. Safety Science, 116(February), 78-85. https://doi.org/10.1016/j.ssci.2019.02.028

Mahjoub, M., Atashsokhan, S., Khalilzadeh, M., Aghajanloo, A., \& Zohrehvandi, S. (2018). Linking "project success" and "strategic talent management": Satisfaction/motivation and organizational commitment as mediators. Procedia Computer Science, 138, 764-774. https://doi.org/10.1016/j.procs.2018.10.100

Martin, M. A. (2020). An evolutionary approach to management control systems research: A prescription for future research. Accounting, Organizations and Society, (xxxx), 101186. https://doi.org/10.1016/j.aos.2020.101186

Prasetyono, H. (2016). Graduate Program Evaluation in the Area Leading Educational, Outlying and Backward. Journal of Education and Practice, 7(36), 109-116.

Prasetyono, H., Kurniasari, D., \& Desnaranti, L. (2019). Evaluation of the implementation of Batik-skills training program. Research and Evaluation in 
Education, 5(2), 130-143. https://doi.org/10.21831/reid.v5i2.23918

Prasetyono, H., \& Ramdayana, I. P. (2020). Pengaruh servant leadership, komitmen organisasi dan lingkungan fisik terhadap kinerja guru. Jurnal Akuntabilitas Manajemen Pendidikan, 8(2), 108-123. https://doi.org/10.21831/jamp.v8i2.28458

Prasetyono, H., Ramdayana, I. P., \& Estiningsih, W. (2020). Peningkatan Kinerja Guru SMK melalui Lingkungan Kerja dengan Mengoptimalkan Efektivitas Kepemimpinan dan Komitmen Tugas. Jurnal Manajemen Dan Supervisi Pendidikan, 4(3), 255-266.

Robbins, S. P., \& Coulter, M. (2012). Management (Eleventh E). Boston: Prentice Hall.

Robert Kreitner. (2009). Management (Eleventh). Boston: Houghton Mifflin Harcourt.

Samagaio, A., Crespo, N. F., \& Rodrigues, R. (2018). Management control systems in high-tech start-ups: An empirical investigation. Journal of Business Research, $\quad$ 89(December), https://doi.org/10.1016/j.jbusres.2017.12.028

Sefudin, A., Prasetyono, H., \& Sasmoko, A. (2014). Implementasi Balanced Scorecard di Koperasi Karyawan dan Dosen Universitas Indraprasta PGRI (UNINDRA). Jurnal of Applied Business and Economics, 1(1), 31-46.

Speklé, R. F., \& Widener, S. K. (2020). Insights on the use of surveys to study management control systems. Accounting, Organizations and Society, (xxxx). https://doi.org/10.1016/j.aos.2020.101184

Spivack, A. J., \& Woodside, A. G. (2019). Applying complexity theory for modeling human resource outcomes: Antecedent configurations indicating perceived location autonomy and work environment choice. Journal of Business Research, 102(May), 109-119. https://doi.org/10.1016/j.jbusres.2019.05.006

Twizeyimana, J. D., \& Andersson, A. (2019). The public value of E-Government A literature review. Government Information Quarterly, (June 2017), 1-12. https://doi.org/10.1016/J.GIQ.2019.01.001

Wei, H., Sewell, K. A., Woody, G., \& Rose, M. A. (2018). The state of the science of nurse work environments in the United States: A systematic review. International Journal of Nursing Sciences, 5(3), 287-300. https://doi.org/10.1016/j.ijnss.2018.04.010

White, C. (2004). Strategic Management. New York: PALGRAVE MACMILLAN.

White, E. M., Aiken, L. H., Sloane, D. M., \& McHugh, M. D. (2020). Nursing home work environment, care quality, registered nurse burnout and job dissatisfaction. Geriatric Nursing, 41(2), 158-164. https://doi.org/10.1016/j.gerinurse.2019.08.007 
Yustien, R. (2012). Pengaruh Penerapan Sistem Pengendalian Manajemen Pada Pusat Pendapatan Dan Pusat Biaya Terhadap Kinerja Manajerial Rumah Sakit Umum Tipe B Di Provinsi Jawa Barat. Pekbis Jurnal, 4(1), 44-53. 